\title{
2 ThE IMPACT OF PARTICIPATION ON NEIGHBOURHOOD BELONGING
}

In this study, neighbourhood belonging is understood to consist of three dimensions: social embeddedness, place attachment, and co-responsibility ${ }^{5}$. While the comparative analysis of the effects of participation on neighbourhood belonging shows the general relevance of these three dimensions at the neighbourhood level, resident interpretations and perceptions are very diverse.

With regard to the investigated initiatives, the analysis suggests a rather weak influence of top-down initiatives on neighbourhood belonging in both cities. In contrast, participation in bottom-up or hybrid initiatives tends to show a stronger relation to neighbourhood belonging. Other - more general - key factors that contribute to residents' belonging include having family members and friends in the neighbourhood, knowing the area well and feeling safe.

Social embeddedness was framed differently in the two cities: in Amsterdam the focus was put on the varying depth of social (interethnic) contacts, whereas the Viennese results highlight the importance of social spaces. While these spaces - which can be both public and institutionalised - are often used for bonding activities within distinct ethnic groups, they play a less important role in connecting groups of different ethnic composition. While some community spaces are used by different ethnic groups, the dominance of some groups may create exclusionary effects. In order for local initiatives to provide low threshold meeting places and build sustainable networks in the neighbourhood, funding is of key importance. Due to increasing competition, longterm strategies are at risk and the created spaces of encounter become fragile. Planning uncertainty in combination with people-dependent bottom-up structures may impede the creation of social contacts in the long-run. The study also shows the relevance of the political dimension of social embeddedness with regard to resident groups 'being heard'; this includes the accessibility of local policymakers and easily accessible neighbourhood funds that can be used to organise initiatives. Interactions between residents and local policymakers can thus also contribute to social embeddedness.

Similarly, place attachment was conceptualised differently in the two cities: while the focus in Amsterdam was primarily on social aspects that contribute to place attachment, in Vienna the role of spatial and physical aspects was highlighted. In both cases, many residents' daily activities and routines take place primarily in the studied neighbourhoods. Aesthetics, location and spatial characteristics (such as density of buildings and access to public space) influence the feeling of 'where one likes to live'. Viennese results show that when options of 'escaping overused spaces' in the neighbourhood are available, this influences positively an individual's resilience

For more details on the conceptual understanding, see: HoEKSTRA and DAHLVIK (2016); ICEC website: www.icecproject.com/project/theory 
when coping with increased diversity. The study found rather weak effects of (non-) participation on place attachment.

Finally, co-responsibility completes our understanding of neighbourhood belonging; it is a rather established concept (also politically) in Amsterdam, whereas it is relatively new in the Viennese context. Given the common understanding of coresponsibility as the collaborative interaction between residents and practitioners, but also stakeholders' creation of public value, our analysis may add to a more residentdriven understanding of co-responsibility. If co-responsibility is supported and strengthened by public stakeholders and policymakers, this might increase residents' sense of neighbourhood belonging. However, requiring co-responsibility from residents can also become a burden and create frustration and disappointment, if they are not provided with long-term support and acknowledgment. Keeping bureaucratic tasks to a minimum is also crucial. To conclude, co-responsibility is perceived differently among residents and strongly depends on the availability of personal resources such as time, information and self-confidence. Participants in local initiatives should be valued as active residents who care about themselves and their role in the neighbourhood, as they are likely to be or become co-responsible residents.

\subsection{The role of: Social embeddedness}

As a dimension of neighbourhood belonging, social embeddedness covers social ties and contacts, from friendships to very casual encounters. It is about who people meet, deliberately or otherwise, and how they experience these contacts. The study shows that people have different expectations and desires with respect to neighbourly relations, including interethnic relations. A broad pattern that emerges is that closer social ties exist more often with those neighbours who are more proximate (e.g. direct neighbours or those living in the same complex) and with people who are more ethnically 'similar'. The role of neighbourhood initiatives in social embeddedness lies primarily in creating more fleeting, superficial encounters between people who might not otherwise know each other and which thereby generate a wider sense of comfort in the neighbourhood. However, initiatives can also create negatively experienced social contacts and conflicts.

\subsubsection{Amsterdam: Fleeting encounters as prerequisite for social embeddedness}

Neighbourhood initiatives increase social embeddedness for participants mostly through an increase in superficial, fleeting encounters at the site of the initiative and in the neighbourhood in general. These encounters consist, for example, of exchanging greetings or small talk with passers-by, shopkeepers, or other participants during organised activities. As a consequence of participating in neighbourhood initiatives, 
participants start to recognise and acknowledge more 'familiar faces' in the neighbourhood and become a familiar face to others as well.

While these contacts are 'lighter' than the organisers of some initiatives envisioned, they are nevertheless highly appreciated by participants. Participation results in increased public familiarity both directly - because participants run into each other in the neighbourhood - and indirectly, for example, when participants interact more with strangers because they experience less cultural distance as a result of their participation. Small-scale contacts across ethnic boundaries are especially increased in this manner.

Deeper or more sustained social contacts can also develop as a consequence of participation, with some interviewees having made friends at activities. This is, however, the exception rather than the rule. Interviewees usually distinguish between social roles (e.g. neighbour/co-participant/friend/relative) and have distinct social expectations for these categories. While some become friendly with other participants during activities, they emphatically state that they do not consider them friends. Particularly for participants of non-Dutch descent, or those who have recently moved into the neighbourhood, participation is a way to 'get out of the house' and be in the company of other people. These participants indicate that they felt isolated before they became active, and that their participation has made them more active in general and has given them the confidence to 'explore' the neighbourhood and surrounding areas.

Interethnic encounters with other participants are not always experienced positively. Language is often a barrier, particularly for those who do not speak Dutch well and/or when there is no common language between participants. Participants who speak 'minority languages' in the context of the particular initiative indicate that they feel excluded by others who are unwilling to talk to them in Dutch. Many of the selected initiatives strive to offer a space that is akin to a 'living room', where residents are free to walk in and socialise, and are encouraged to feel at home. This ideal of homeliness can be at odds with the goal of inclusivity. Certain activities can become dominated by residents of particular ethnic (sub)groups who, whether intentionally or not, make participants of a different ethnic background feel unwelcome. In some initiatives this was avoided by active moderation of activities and group discussions.

Another risk to social relations in the larger neighbourhood is the competition between different initiatives for funding or other resources. Having to share neighbourhood locations can easily lead to tensions, as does the perception that the distribution of resources between initiatives is unequal. Conflicts that did not start out as interethnic ones (such as generational conflicts around the use of public and semi-public spaces) easily become interpreted along ethnic lines. 


\subsubsection{Vienna: Dominance of intra-group networks}

With regard to social embeddedness, the Viennese case study suggests that individuals often face a dilemma between anonymity and social control. On the one hand, some interviewees would like to have better contacts with their in-house neighbours; on the other hand, many fear that they could be considered nosy neighbours. At the same time, intergenerational divides (e.g. between students and the elderly) and the high fluctuation of neighbours were identified as barriers for new in-house contacts. We also found that interviewees' social networks exist to a large degree within, rather than beyond, the own ethnic group. In general, residents tend to accept living side-by-side in the neighbourhood as long as there are no severe conflicts.

The design of the research also allows us to differentiate between horizontal and vertical contacts. In the neighbourhood, different institutionalised and noninstitutionalised spaces of encounter such as kindergartens, playgrounds, parks or pubs function as meeting points for residents where horizontal contacts arise, are established and maintained. The studied initiatives facilitated horizontal contacts to different degrees. While, for example, the courses at the Neighbourhood Centre provide the possibility of long-term contacts, the structure of Gardening around the Corner rather promotes contacts between participants and strangers on the street. The latter initiative simultaneously enables vertical contacts to institutions (Urban Renewal Office and district government). Concerning vertical contacts, the Neighbourhood Centre in Vienna was mentioned as another example of a relevant social institution, for instance, with respect to providing advice and services. In Gumpendorf $\left(6^{\text {th }}\right)$, several interviewees mentioned the district mayor as a contact person for issues regarding the neighbourhood; this gives residents the feeling of 'being heard'. In the other neighbourhoods, vertical contacts were rarely mentioned, which might imply that possibilities to develop such contacts, that is possibilities to meet relevant actors, are underdeveloped there.

The Viennese case study also examined how spaces of encounter can function as bridges between different groups. As such spaces primarily tend to strengthen bonding within a group, it is more difficult to make them work as bridging venues between groups. Planning departments might play a more active role in designing meeting places that facilitate get-togethers. Also, a new understanding of success and 'places that work' needs to be developed. It is important to accept that negative or conflictual contacts might also be necessary, or at least unavoidable, in order to create social embeddedness. Here, mediating actors such as Fairplay or Wohnpartner can play a crucial role in facilitating communication amongst neighbours. In addition, social embeddedness can also be promoted through sports, school, culture, and politics. 
ZUSAMMENFASSUNG:

In diesem Forschungsprojekt wird das Zugehörigkeitsgefühlzueiner Nachbarschaft auf der Basis von drei Dimensionen analysiert: soziale Einbettung, lokale Verbundenheit und das Gefühl der Mitverantwortlichkeit. Während die vergleichende Analyse der Effekte der Beteiligung an lokalen Initiativen bezüglich des Zugehörigkeitsgefühls eine generelle Relevanz dieser drei Dimensionen auf der Ebene der Untersuchungsviertel bestätigt, sind die individuellen Wahrnehmungen und Interpretationen der BewohnerInnen in Bezug auf diese Konzepte sehr divers. Mit Hinblick auf die untersuchten Initiativen spiegelt die Analyse für beide Städte einen schwächeren Einfluss von Top-down-Initiativen auf das Zugehörigkeitsgefühl zur Nachbarschaft wider. Im Gegensatz dazu besteht bei Bottom-up- und hybriden Initiativen eine stärkere Tendenz in Richtung einer Stärkung des Zugehörigkeitsgefühls zur Wohnumgebung. Weitere generelle Schlüsselfaktoren, die positiv zum Zugehörigkeitsgefühl beitragen, sind in der näheren Umgebung lebende Familienmitglieder und Freunde, eine gute räumliche Kenntnis des Stadtviertels sowie ein Gefühl subjektiver Sicherheit.

\section{SAMENVATTING:}

Onder inbedding in sociale netwerken verstaan we de contacten die mensen opdoen in de buurt. Het kan hierbij gaan om hechte vriendschappen, maar ook om goede burenrelaties of het groeten van vage bekenden (zogenaamde horizontale contacten), evenals contacten met instanties en hulpverleners in de buurt (verticale contacten). Onze analyse laat zien dat bewoners verschillende verwachtingen en wensen hebben ten aanzien van sociale contacten in de buurt. Soms zijn deze wensen ook tegenstrijdig: men wil meer buurtbewoners leren kennen maar is ook gesteld op de eigen privacy. Over het algemeen zijn vaker voorkomende en meer diepgaande contacten vaak met naaste buren en met mensen die meer op de gë̈nterviewde lijken (bijvoorbeeld mensen van dezelfde etnische groep, of mensen in dezelfde gezinssituatie). De bijdrage van buurtinitiatieven aan inbedding in sociale netwerken bestaat voor de deelnemers vooral uit een toename van oppervlakkige contacten, zoals groeten op straat of een kort praatje maken. Deze contacten worden door de deelnemers echter wel gewaardeerd en dragen volgens hen bij aan hun thuisgevoel. Daarnaast worden sociale contacten opgedaan binnen initiatieven niet altijd positief ervaren: wanneer een kleine groep met dezelfde achtergrond het goed met elkaar kan vinden, voelen anderen zich soms buitengesloten. Met name de brugfunctie tussen verschillende groepen is daarom voor buurtinitiatieven vaak moeilijk te vervullen. 


\subsection{The role of: Place and neighbourhood attachment}

Place attachment can refer to a place where one likes to live or spend time. In our research across the two cities, some residents claim to be rather indifferent to places and spaces, highlighting the stronger importance of social ties. While positive aspects of place attachment include using and taking care of neighbourhood spaces, it can also have negative aspects, for instance, when certain groups' claims of public space exclude other groups from accessing, or feeling safe and comfortable in these spaces. Activities that take common fields of interest as a point of departure, such as childcare or sports, can promote place attachment. Since urban design of public space can influence an individual's identification with space, reinventing public space can also contribute to enhancing place attachment. In some cases, public spaces are no longer used as the needs of residents have changed. Also, different social groups tend to use public spaces at different times over the course of the day. Is it possible to create a public space where all residents feel comfortable?

\subsubsection{Amsterdam: Social networks go beyond neighbourhoods}

The neighbourhood is not necessarily a place of attachment for the interviewed residents. Social networks and daily trajectories often encompass a larger area than just the neighbourhood. Nevertheless, many interviewees indicate that they spend the majority of their daily life in the neighbourhood. Uniformly appreciated in the studied neighbourhoods are connections to the rest of the city through the neighbourhood's location and the availability of nearby public transport, and the presence of greenery and parks. 'Native' Dutch informants are more likely to feel connected to the historical and aesthetic aspects of the neighbourhood, while residents with a migration background are more likely to stress social contacts and neighbourhood amenities.

It is not clear how participation in local initiatives influences place attachment. In some cases, participants indicate that they got to know the neighbourhood better through the initiative. However, this mostly relates to social rather than physical aspects. Others state that, due to their involvement, their perception of neighbourhood boundaries has changed. Whereas before they only felt attached to a small area (their street or apartment block), due to their involvement the area that they view as 'their' neighbourhood has become larger. Finally, for some respondents, attachment to the physical area is a motivation to become involved, in order to influence the direction of (future) urban renewal operations. 


\subsubsection{Vienna: The role of 'compensation spaces' outside overcrowded neighbourhoods}

Regarding place attachment, the Viennese case study findings show that interviewees seem to be more attached to the neighbourhood in the Gumpendorf $\left(6^{\text {th }}\right)$ district than in Breitensee $\left(14^{\text {th }}\right)$ or the Hippviertel $\left(16^{\text {th }}\right)$. This observation might be related to the 'urban village character' of the Gumpendorf neighbourhood, but also that the neighbourhood is regarded as rather prestigious, especially by residents with an immigrant background. In addition, the comparably higher socioeconomic status of many residents in Gumpendorf enables them to 'escape' from city life, be it to an allotment garden or a weekend cottage; these serve as 'compensation spaces' for overused and limited private spaces in the city. Noise, overuse, and limited options for privacy makes residents want to 'escape from the neighbourhood' in Hippviertel $\left(16^{\text {th }}\right)$ as well. In contrast to Gumpendorf, the spatial radius of respondents is smaller, consisting mostly of larger open spaces within the city boundaries. In Breitensee $\left(14^{\text {th }}\right)$, respondents mostly emphasised the availability of green and open spaces and did not indicate a need for compensation spaces.

To summarise, a direct connection between participation and place attachment in Vienna could not be established for most analysed initiatives. While the bottom-up initiatives in the $14^{\text {th }}$ district show such a link, as with the Amsterdam result, this effect rather applies to social rather than to physical aspects.

\section{Reflections from Practitioners in Urban and Regional Planning in Stockholm:}

The analysis suggests a rather weak influence of top-down initiatives. From a planning perspective, this is not an issue when collecting valuable information for future measures in social planning. The initiatives in Stockholm are mostly considered hybrids, with top-down inputs mostly in the form of public funding and less so in terms of strategic competencies, know-how and tacit knowledge.

Swedes have a strong culture of private associations, whom often engage in different associations during their lifetime, ranging from sport clubs, handicrafts and housing to book clubs, etc. The structure of these associations, including the analysed initiatives, offers inclusive interaction of citizens. These underlying structures can strengthen the success of initiatives and create conditions for frameworks designed to provide residents with long-term opportunities for interaction in neighbourhoods and at a regional level. Given that strategies for planning, implementation and longterm commitment are being developed, it is possible to capture functional parts of the initiative and make strides towards co-creation. 
Social cohesion in a Swedish context is highly dependent of population and area. Rågsved and Rinkeby, can, to a greater extent than most other neighbourhoods, be perceived as transit areas. Rinkeby has historically had a cycle where the composition of cultural background of residents has varied after periods of approximately 5-10 years. In Rågsved, many inhabitants report that they do not plan to stay for long, even if they enjoy the neighbourhood. The opportunity of housing in the area decided the place to live, and they plan on moving later. This makes it difficult to establish long-term relationships based on the areas. It rather becomes a matter of common interests or personal networks. Initiatives with an inter-ethnic composition opens up for cultural exchanges in a form where participants can feel comfortable in the community. In Stockholm, a problem of mixing ethnicities cannot be seen as a problem; it is rather a challenge to bring together Swedes with non-Swedes. Language barriers seem to be an non-issue in the Stockholm case, in some cases the language instead connects people for example in "Swedish with baby", at Open Pre-school, and "Language cafe", at Folkets Hus. Swedish Mekteb has a policy to always use Swedish within their organisation (but they also teach Arabic). Common to many participants, is that before they started participating in the initiative, they felt that they were isolated, something also described in the other cities.

Resources that create barriers can be seen in the Future Committee, where, for example, night-guardians do not share their resources despite the same goal. In the Future Committee, the local city administration representatives are present, their role mostly consisting of listening and providing information. But there is also an expectation on behalf of the participants that they will assist with support, either in the form of funding or in the form of contacts or access to decision-makers. The process regarding roles and room for manoeuvre is ongoing, and it is probably a crucial element for building a level of trust. This is even more important in a regional context and for regional public officials where the lack of direct operational action requires that they specify their role as being more broad and at the conceptual level: regionalising best practice from local contexts, coordination and cooperation of stakeholders, and bringing different levels of stakeholder together.

The importance of active participation is not limited to residents; it is also important that commitment is shown vertically. Vertical contact can be strengthened through initiatives with the visible participation of the public authorities.

My 127 and Swedish Mekteb promote sustained social contacts, while several initiatives provides a forum for spontaneous gathering. The social contacts that are created can also have a special effect, visible within the concept of the My 127 festival, now inspiring other neighbourhoods in several places throughout the country. The importance of the site is vital in many ways, including how the place or venue is used. My 127 is a site-based initiative that opens up an area for exploration and discovery by far more people that would normally visit the area. This shows how the flexible use of existing places and venues can benefit sustainable interaction with and between residents and that the regional actors must be active to maximise utilisation. 


\section{ZUSAMMENFASSUNG:}

Lokale Verbundenheit bezieht sich auf eine Örtlichkeit, an der man gerne lebt oder wo man gerne seine Zeit verbringt. Im vorliegenden Städtevergleich gaben viele BewohnerInnen an, dem räumlichen Aspekt indifferent gegenüberzustehen. Vielmehr spielen soziale Bindungen eine größere Rolle. Während positive Aspekte der Verbundenheitzu einem Ortauch dieNutzung undFürsorge für das räumliche Wohnumfeld inkludieren, können diesbezüglich auch negative Effekte auftreten. Beispielsweise, wenn bestimmte Gruppen Anspruch an den öffentlichen Raum erheben und damit andere Gruppen von der Nutzung desselben ausschließen oder deren Sicherheitsgefühl bzw. das Sich-Wohlfühlen in diesem Raum beeinträchtigen. Aktivitäten, die als gemeinsame Interessenbereiche den Ausgangspunkt bilden, wie etwa Kinderbetreuung oder Sport, können die lokale Verbundenheit fördern. Da Stadtgestaltung und Architektur die Identifikation von BewohnerInnen mit diesen Orten in der Nachbarschaft beeinflusst, kann die Neuerfindung des öffentlichen Raums ebenfalls zur Verstärkung lokaler Verbundenheit beitragen. In manchen Fällen werden öffentliche Teilräume nicht mehr genutzt, da sich die BewohnerInnenbedürfnisse verändert haben. Unterschiedliche soziale Gruppen nutzen den öffentlichen Raum zu unterschiedlichen Zeiten während des Tages, aber auch in den Nachtstunden. Ist es also möglich, städtischen Raum so zu strukturieren, dass dieser allen BewohnerInnen die Option bietet, sich darin wohlzufühlen? Zusammenfassend ist festzustellen, dass ein direkter Bezug zwischen der Teilnahme an Aktivitäten und lokaler Verbundenheit seitens der meisten Initiativen nicht hergestellt werden konnte. Während die Bottom-up-Initiativen im 14. Bezirk einen solchen Effekt zeigten, ganz ähnlich den Resultaten in Amsterdam, bezog sich dieser aber eher auf soziale als auf physisch-räumliche Aspekte.

\section{SAMENVATTING:}

Hechting aan de omgeving gaat om een band met de plek waar je leeft of je tijd doorbrengt. Uit onze vergelijkende analyse blijkt dat de fysieke omgeving voor veel bewoners niet zozeer van belang is, maar dat zij zich vooral thuisvoelen door de sociale contacten die ze in de buurt hebben. Wanneer bewoners positief zijn over hun leefomgeving benadrukken ze met name de locatie van de buurt, aanwezige (groen) voorzieningen en toegang tot goed openbaar vervoer. Er zijn echter ook negatieve ervaringen, bijvoorbeeld wanneer de openbare ruimte door bepaalde groepen wordt geclaimd en daardoor minder toegankelijk is voor anderen, hetzij doordat zij er daadwerkelijk geen gebruik meer van kunnen maken hetzij omdat de aanwezigheid van andere groepen zorgt voor een verminderd veiligheidsgevoel (bijvoorbeeld in het geval van, hangjongeren'). Het ontwerp van de publieke ruimte kan zeker bijdragen aan thuisgevoel, en hier zitten wellicht ook aanknopingspunten voor beleid. Denk bijvoorbeeld aan het inventariseren van welke groepen op welke momenten van de dag gebruik maken van bepaalde plekken in de buurt, en hoe dat op zijn beurt weer het thuisgevoel van anderen beïnvloedt. Deelname aan initiatieven heeft in beide steden 
geen sterke invloed op hoe de fysieke ruimte wordt ervaren. Wel is het zo dat dit soort initiatieven de perceptie van de buurt en van buurtgrenzen kan veranderen, doordat deelnemers bijvoorbeeld in een deel van de buurt komen dat niet op hun dagelijkse route ligt.

\subsection{The role of: Co-responsibility}

According to the Council of Europe, co-responsibility is an overarching concept that includes four key themes: living environment, social balances and sense of belonging, relations between people and with institutions, and commitment and participation (see Bloomfield 2012). As Bloomfield (2012) argues, six steps are necessary in order to achieve co-responsibility: minimal engagement, formal and engaged partnerships, co-governance, co-management, co-production, and finally co-responsibility. Coresponsibility can thus be defined as the final phase of a long-term development and integration process. It thus has a high threshold since it requires a high level of interaction. Currently, the first two steps, engagement and partnerships, can be observed in the neighbourhood case studies in both Amsterdam and Vienna.

In our study, depending on the local (or national) context, co-responsibility can be understood as either residents and (political) practitioners working together (which is the case in Austria) or as governments and municipalities handing over responsibility - particularly for neighbourhood maintenance - to residents (which is the case in Amsterdam). In our interviews with residents, both participants and non-participants, coresponsibility was often understood as referring to the responsibility of each resident for peaceful coexistence, for the neighbourhood and its development.

\subsubsection{Amsterdam: The risk of feeling exploited}

In Amsterdam, participation in neighbourhood initiatives influences coresponsibility in a number of ways. First, local initiatives assist residents who might be in a marginal position in a highly accessible way; interviewed participants greatly appreciate this informal help from local professionals or active residents. Even when there is also formal assistance available (as is often the case), vulnerable residents might prefer help in the form of a neighbourhood centre where they can drop-in and receive assistance on a multitude of topics without an appointment. Volunteers at these centres often speak their language and know about relevant personal and cultural circumstances. In this way, residents can become more empowered in their daily lives, exchange information, and come into contact with others who have (had) similar experiences. Stakeholders of initiatives also use these kinds of services to draw people in, who they then encourage to become active in other ways. 
Second, participants who are more actively involved in planning and organising activities indicate that they feel responsible for the reputation of the neighbourhood, its future development, and the social situation of their fellow residents. They enjoy being known in the neighbourhood as someone people can approach if they are in need of assistance. While some experience personal fulfilment, many also feel overburdened. As familiar faces in the neighbourhood, they are approached by other residents for information or advice, which can be time-consuming and make people feel like they are always 'on duty'.

Boundaries need to be established not just as regards other residents, but also in dealing with professionals, who sometimes expect too much time and commitment from unpaid volunteers. Another challenge is the ambiguous position of active residents as on the one hand representing and advocating for the neighbourhood residents, and on the other hand being expected to help enforce 'common norms' and liveability standards. For example, the neighbourhood ambassador is sometimes seen by fellow residents as an institutional representative, and therefore has to deal with the mistrust and anger of some residents who do not want to be told how to behave, or who are afraid that their personal information will be passed on to institutions. Another frustrating aspect of active involvement is the necessity to navigate bureaucratic requirements. Application procedures for subsidies often represent an obstacle and deterrent for lower educated residents, whereas higher educated active residents tend to view this as networking and learning opportunities.

Finally, some participants describe their motivation for becoming active as a reaction to institutions (the district government, housing associations, welfare organisations) neglecting what residents consider to be their duties, thereby 'forcing' participants to take matters into their own hands. As such, they can only be described as 'reluctantly co-responsible'. This goes along with a considerable disenchantment with institutions, especially from the side of those residents who are the most active.

\subsubsection{Vienna: Lacking awareness of 'power to affect change'}

Our data from the Viennese case study illustrates that turning activity and participation into co-responsibility is a complex task. Interviewees generally regard co-responsibility to be an important issue, especially in relation to possible conflicts in the neighbourhood. Nevertheless, the question of individual capacities for co-responsibility arises, with personal overload or time limitations often representing barriers to engagement in local activities. Especially in socially distressed neighbourhoods with a high share of single-parent or unemployed households, time and financial constraints are the main reason for not becoming more active. Residents who are active in the sense of 'participating in initiatives' still need to be supported in order to promote coresponsibility in the neighbourhood. Otherwise, only those residents with the relevant 
capacities will be involved in shaping their neighbourhood. Moreover, co-responsibility is difficult to activate if there is a general lack of belonging or feeling of attachment to the neighbourhood by residents. Those who do feel responsible and become active in a self-organised, bottom-up initiative are often highly educated, rather homogenous groups that are used to demanding services from the local administration (e.g. financial subsidies, permissions).

Finally, our analysis identifies a lack of understanding among residents with regard to self-responsibility and their 'power to affect change'. The analysis of the Viennese case study highlights the effect of a historically grown habitus within a social welfare state regime. From this perspective, only the city government and policymakers are perceived by residents to be those who have the power to affect change. This might be a starting point both for policymakers and broader society to have a debate about coresponsibility at the local level.

In order to promote co-responsibility, a focus on similarities and common interests among groups seems vital. The findings suggest that residents should be involved in long-term decision-making and planning, even though it is often a complex and longterm process. A long-term vision and funding security seems vital for creating coresponsibility through participation in initiatives.

\section{Reflections from Practitioners in Urban and Regional Planning in Stockholm:}

As in Amsterdam and Vienna, Stockholm too had engagement and partnerships between residents, active local ambassadors, active participants not residing in the neighbourhoods, and local public officials, business community leaders, and NGO representatives. Initiative managers often seem to assume the role of speaking partner for participants on all kinds of issues and a source of information on where to go to get things done or whom to talk to. A similar position can be observed for some of the local administration officers, who work in the area. A specific challenge here is to what extent local ambassadors manage to connect with the other locals and furthermore to interact with public officials so as to go from the operational level to engage in a more strategic manner. Likewise, the ability of local public officials to engage, which often means working late at evenings as most meetings take place then and move around in the neighbourhood. The networking bridge appear to be one of the most important ones for building trust. Co-responsibility is otherwise a rather unfamiliar concept in Sweden, and if used it is most often introduced in specific projects related to housing associations rather than in requesting citizens to assume responsibility for traditional municipal services. 


\section{ZUSAMMENFASSUNG:}

In unserer Studie kann Mitverantwortlichkeit einerseits so verstanden werden, dass BewohnerInnen und PraktikerInnen zusammenarbeiten (wie in Wien) oder dass die Stadtverwaltung die Verantwortlichkeit, im Besonderen für die Instandhaltung des Wohnumfelds, an die BewohnerInnen delegiert (dies ist in Amsterdam der Fall). In unseren Interviews wurde Mitverantwortlichkeit oft verstanden als die Verantwortlichkeit jedes/-r Bewohners/-in für ein friedliches Zusammenleben, für das Wohnumfeld als solches und seine Entwicklung. In Amsterdam beeinflusst die Teilnahme an Initiativen die Mitverantwortlichkeit auf vielerlei Weise. Erstens, indem lokale Initiativen marginalisierten BewohnerInnen informelle Hilfestellungen zukommen lassen, zweitens indem TeilnehmerInnen aktiv in Planungs- und Organisationsaktivitäten einbezogen werden, was zeigt, dass diese sich verantwortlich für die Reputation und die künftige Entwicklung des Wohnviertels fühlen, und drittens als Reaktion auf Institutionen (Bezirksverwaltungsbehörde, Wohnungsgenossenschaften), die ihre Pflichten gegenüber den BewohnerInnen vernachlässigen. Für Wien zeigt sich, dass die Überführung von aktiver Beteiligung in Mitverantwortung eine komplexe Aufgabe darstellt. Zwar wird letztere von den meisten Interviewten als wichtig angesehen, es besteht jedoch ein Defizit an Eigenverantwortlichkeit und der Überzeugung von der eigenen Fähigkeit, Veränderungen bewirken zu können. Die Wiener Fallstudien spiegeln die Effekte eines historisch gewachsenen Verhaltens innerhalb stabiler sozialstaatlicher Strukturen wider. Zum Zweck der Förderung der Mitverantwortlichkeit ist die Fokussierung auf Ähnlichkeiten zwischen und gemeinsame Interessen verschiedener Gruppen unerlässlich. Die BewohnerInnen sollen in langfristige Entscheidungsprozesse und Planungen eingebunden werden, was oft komplexe Abläufe erfordert. Eine langfristige Vision und Finanzierungssicherheit stellen unerlässliche Voraussetzungen für die Förderung von Mitverantwortung dar.

\section{SAMENVATTING:}

In ons onderzoek bestaat mede-verantwoordelijkheid uit ofwel bewoners die samenwerken met mensen uit het maatschappelijk of beleidsveld (zoals vaak het geval is in Wenen) of overheden die taken en verantwoordelijkheden met betrekking tot de buurt overdragen aan bewoners (zoals vaak het geval is in Amsterdam). Uit onze interviews met bewoners, zowel deelnemers aan buurtinitiatieven als niet-deelnemers, blijkt dat zij mede-verantwoordelijkheid vaak opvatten als de taak van elke bewoners om bij te dragen aan vreedzaam samenleven en aan de buurt in het algemeen. In Amsterdam blijkt de belangrijke rol van buurtinitiatieven bij het stimuleren van mede-verantwoordelijkheid onder andere uit de vele actieve bewoners die een groot deel van hun tijd en energie steken in activiteiten voor de buurt. Hiermee wordt ook meteen duidelijk dat de afhankelijkheid van veel initiatieven van vrijwilligerswerk ook een schaduwzijde kent: actieve bewoners worden makkelijk overbelast en voelen zich soms klem zitten tussen de verwachtingen van de lokale overheid enerzijds en die van hun medebewoners anderzijds. Sommige 
geïnterviewden waren dan ook kritisch over de door hun gevoelde, burgerplicht 'om te participeren in de buurt, en stellen dat instanties meer werk zelf moeten oppakken. Ook in Wenen blijkt mede-verantwoordelijkheid een complex begrip. Veel bewoners vinden zichzelf niet in staat om meer verantwoordelijkheid te nemen, of willen dit wel maar weten niet hoe ze dit aan kunnen pakken. Dit komt ook door de institutionele structuur waarbij de overheid van oudsher veel voor de bewoners verzorgt en er niet zozeer een beroep op bewoners wordt gedaan om zelf met initiatieven te komen. De groepen die zichzelf wel organiseren, bestaan dan ook vaak uit hogeropgeleiden die weten hoe ze dingen gedaan moeten krijgen. 